\title{
Phenomenology of Practice
}

\author{
Max van Manen, University of Alberta \\ Email: max.van.manen@ualberta.ca
}

\begin{abstract}
If I were to tell you where my greatest feeling, my universal feeling, the bliss of my earthly existence has been, I would have to confess: It has always, here and there, been in this kind of in-seeing, in the indescribably swift, deep, timeless moments of this divine seeing into the heart of things.
\end{abstract}

(Rainer Maria Rilke, 1987)

\section{Abstract}

Phenomenology of practice is formative of sensitive practice, issuing from the pathic power of phenomenological reflections. Pathic knowing inheres in the sense and sensuality of our practical actions, in encounters with others and in the ways that our bodies are responsive to the things of our world and to the situations and relations in which we find ourselves. Phenomenology of practice is an ethical corrective of the technological and calculative modalities of contemporary life. It finds its source and impetus in practical phenomenologies of reading and writing that open up possibilities for creating formative relations between being and acting, self and other, interiorities and exteriorities, between who we are and how we act.

\section{Introduction}

Phenomenology is a project of sober reflection on the lived experience of human existencesober, in the sense that reflecting on experience must be thoughtful, and as much as possible, free from theoretical, prejudicial and suppositional intoxications. But, phenomenology is also a project that is driven by fascination: being swept up in a spell of wonder, a fascination with meaning. The reward phenomenology offers are the moments of seeing-meaning or "in-seeing" into "the heart of things" as Rilke so felicitously put it. Not unlike the poet, the phenomenologist directs the gaze toward the regions where meaning originates, wells up, percolates through the porous membranes of past sedimentations - and then infuses us, permeates us, infects us, touches us, stirs us, exercises a formative affect. 
In-seeing takes place in a thoughtful relation to what Heidegger (1985) calls "in-being" or our everyday being-involved-with the things of our world. In-being is the constitution of the sense of being, in which every particular mode of being finds its source and ground. So, when Martin Heidegger says, "Knowing is a mode of being of in-being" then this means that every moment of practical acting and knowing always already takes place in a mode of being that he calls in-being (1985, p. 161). A phenomenology that is sensitive to the lifeworld explores how our everyday involvements with our world are enriched by knowing as in-being.

As teachers and researchers we are interested in the promise that phenomenology can make to practice. But Heidegger warns that phenomenology "never makes things easier, but only more difficult" (2000, p. 12). He agrees with those who feel that phenomenology lacks effectiveness or utility if one hopes to do something practically useful with it:

"Nothing comes" of philosophy; "you can't do anything with it." These two turns of phrase, which are especially current among teachers and researchers in the sciences, express observations that have their indisputable correctness .... [It] consists in the prejudice that one can evaluate philosophy according to everyday standards that one would otherwise employ to judge the utility of bicycles or the effectiveness of mineral baths. (2000, p. 13)

The practicality of a phenomenology of practice should not be sought in instrumental action, efficiency or technical efficacy. And yet, that does not mean that phenomenology cannot have practical value.

It is entirely correct and completely in order to say, "You can't do anything with philosophy." The only mistake is to believe that with this, the judgment concerning philosophy is at an end. For a little epilogue arises in the form of a counter-question: even if we can't do anything with it, may not philosophy in the end do something with us, provided that we engage ourselves with it? (2000, p. 13; emphasis in original)

In some sense all phenomenology is oriented to practice - the practice of living. But from the perspective of our pragmatic and ethical concerns we have a special interest in phenomenology. We have questions of how to act in everyday situations and relations. This pragmatic concern I will call the "phenomenology of practice." Thus, we wish to explore how a phenomenology of practice may speak to our personal and professional lives.

Now, in asking whether phenomenology may do something with us Heidegger hints at the formative value of phenomenology. In doing phenomenological research, through the reflective methods of writing, the aim is not to create technical intellectual tools or prescriptive models for telling us what to do or how to do something. Rather, a phenomenology of practice aims to open up possibilities for creating formative relations between being and acting, between who we are and how we act, between thoughtfulness and tact. 


\section{Practice - Theory}

It may be helpful to remind ourselves that the word "practice" has long been used in contrast with the term "theory." Valuing the theoretical life over the life of practice hints at high commitment to truth and contemplating the good life. Thus, theory can mean a rebuttal of practice, but it can also be seen in the service of practice, following practice, or as the essence of practice itself. In his "Praise of Theory" Hans-Georg Gadamer (1998) notes that theoria in its original Greek sense of contemplatio was conducted in a broader context of life and thus was also a way of comporting oneself. He says, it is a "'being present' in the lovely double sense that means that the person is not only present but completely present" (1998, p. 31). Gadamer questions the justification of the oppositional contrast between theory and practice. He asks whether it is perhaps not so much theory but practice itself that points to the sources of meaning of our lives:

But what has happened to our praise of theory, then? Has it become a praise of practice? Just as the individual who needs relevant knowledge must constantly reintegrate theoretical knowledge into the practical knowledge of his everyday life, so also a culture based on science cannot survive unless rationalizing the apparatus of civilization is not an end in itself, but makes possible a life to which one can say "yes." In the end all practice suggests what points beyond it. (Gadamer 1998, pp. 35-36)

If we accept Gadamer's suggestion of praise of theory as praise of practice then some provocative questions present themselves. What then remains of theory in an age where only few are still willing to sing its praises?

An example of a provocative questioning of the significance of theory is the book life.after.theory that contains a series of interviews with prominent scholars such as Jacques Derrida, Frank Kermode, Christopher Norris, and Toril Moi (Payne \& Schad, 2003). The title of the book was chosen first of all to indicate that the period of high theory appears to have passed and now it may be time to ask again about the relation of theory to life. The conjunction "after" in "life after theory" may be understood in different ways. "After" may simply mean the chronology of life following theory, referring to new forms of thought or practice now that theory has vanished, or "after" may suggest that theory has conditioned life, or, vice versa, that life is now after theory in an entirely different sense of that term.

In the opening dialogue of life.after.theory, Derrida offers a surprising but provocative thesis of how he sees the practice of his own life in relation to his writing. He says,

I confess that everything I oppose, so to speak, in my texts, everything that I deconstruct - presence, voice, living, voice and so on-is exactly what I am after in life. I love the voice, I love presence, I love ...; there is no love, no desire without it. So, I'm constantly denying, so to speak, in my life what I'm saying in my books or my teaching .... [In my writing there is] a Necessity which compels me to say that there is no immediate presence, compels me to deconstruct .... 
Nevertheless, in my life, I do the opposite. I live as if, as if it were possible ... somehow to be present with voice, or vocal presence. I want to be close to my friends and to meet them and, if I don't, I use the phone. That's life, consistent with and inconsistent with, following without following ... it's because there is no pure presence that I desire it. There would be no desire without it. (Derrida in Payne \& Schad, 2003, pp. 8-9)

Whereas for Gadamer, theoria refers to an exemplary manner of comporting oneself, in such a way that one is "completely present," Derrida (in the footsteps of Heidegger) has deconstructed the possibility of being "completely present." But what is methodologically even more striking, perhaps, about Derrida's personal reflection is that he is living his personal life in a relation of distinct tension with his life as scholar. His confession is especially revealing to the extent that he goes to great pains to show that he strives for consistency in his scholarly work:

Now, in my own case-I mean, theoretically - I have tried, the best I could, to avoid being inconsistent; I try to write and say and to teach in a certain way which prevents me, as much as possible, from, let's say, contradicting myself or changing. I try. Even if I think, "Well, there are contradictions or aporias in my own text," it is because I am saying things which are self-contradicting or aporetic; so, I point to them and I try to formalize the aporia or the selfcontradiction in order not to be inconsistent, not to say, "Well, that is what I wrote when I was 25." I try not to. (Derrida in Payne \& Schad, 2003, p. 26)

Derrida could argue that there is still consistency in the sense that theorizing is also a form of life, in other words, a practice. Indeed there are good reasons for shifting the focus from the tenuous issue of "life after theory" to the more contemporary concern of "life after practice"- the practice or practices that make up theory, that precede theory, or that make theory (our thinking and writing of it) possible in the first place. If we take the view that a primal notion of practice refers to our ongoing and immediate involvement in our everyday worldly concerns then the mutual relations between practice and thought appear extremely complex and subtle. Numerous phenomenologists have aimed to find vantage points from which we may grasp the ways that reveal how our sensibilities and experiences of the world are formed or conditioned by the primordialities of our existence.

\section{Primordialities of Practice}

In his Phenomenology of Internal Time Consciousness (1964) Edmund Husserl uses the famous example of sound to illustrate how the tones of a piece of music present themselves in the instant of the now; and how the successive retention and protention of melody gives us the experience of time past, present, and future. In Husserl's epistemological language it is the primal impressional consciousness and its retentional and protentional aspects that make our lived experiences potentially available in the form of intentional objects for our reflection. On the one hand, primal 
impressional consciousness is prereflective and thus it manifests itself as an inexhaustible deposit of primordialities that constitute our experiential existence. On the other hand, the experiences that we live through present themselves to us as accessible to reflection and language, according to Husserl:

We must distinguish: the prephenomenal being of experiences, their being before we have turned toward them in reflection, and their being as phenomena. When we turn toward the experience attentively and grasp it, it takes on a new mode of being: it becomes "differentiated," "singled out." And this differentiating is precisely nothing other than the grasping; and the differentiatedness is nothing other than being-grasped, being the object of our turning-towards. (Husserl 1991, p. 132)

So when reflection lifts up and out from the prereflective stream of consciousness the lived experiences that give shape and content to our awareness, reflection interprets what in a prereflective sense already presents itself as a primal awareness. Obviously, there are many philosophical issues associated with these distinctions. For example, is the prereflective stream of consciousness already a conscious experiential awareness? And what is the relation between the passive reflection by which consciousness becomes aware of itself as world, and the more active reflection of thinking? Is prereflective experience already experience of meaning, lived meaning? Or does meaning and intelligibility only emerge at a linguistic or more reflective level of the practice of living?

For Husserl the ultimate source of intelligibility seems to be the primal impressional stream of preconscious life that becomes interpretatively available to our understanding as lived experience. In Husserl's words, "the term lived experience signifies givenness of internal consciousness, inward perceivedness" (Husserl, 1964, p. 177). To say that primal impressionretention-protention is preconscious does not mean that it precedes consciousness, but rather that it is conscious in a primal prereflective sense. It points to the realm that for Husserl is the source and the condition for intelligibility of the experience or practice of living.

Husserl's notion of primal impressions should not really be seen (as is sometimes done) as some kind of elemental building blocks or the contents of our perceptions or cognitions. Rather, one should think of the primal impression-retention-protention as that form of consciousness that presents itself as time-time as we live through it - as the living present before it has been appropriated by reflection. Primal impressional consciousness points to the corporeal and temporal nature of existence. At the level of primal consciousness there is not yet objectification of self and world. Lived experience is simply experience-as-we-live-through-it in our actions, relations and situations. Of course, our lived experiences can be highly reflective (such as in making decisions or theorizing) but from a Husserlian phenomenological point of view this reflective experience is still prereflective since we can retroactively (afterwards) subject it to phenomenological reflection. Only through reflection can we appropriate aspects of lived experience but the interpretability of primal impressional life is already in some sense given by its own givenness. 
Husserl's introduction of primal impressional consciousness is attractive in that it provides a context for conceptualizing the notion of the phenomenological reduction and how phenomenological reflection is possible in relation to the everyday practices of the lifeworld. But not all phenomenologists subscribe to the distinction of primal impressional consciousness. From the perspective of Heidegger's ontology, Husserl's primal impressional consciousness is already an abstraction of how we find ourselves in the world. Heidegger says that we are always already practically engaged in the context of life. For Heidegger the origin of meaning is not found in some primal realm but right here in our actions and in the tactile things of the world that we inhabit.

In contrast with Husserl's explication of the temporality of tone and music, Heidegger emphasizes the meaning of the sound we hear: "We hear the door shut in the house and never hear acoustical sensations of mere sounds” (1975, p. 25). When we hear the sound of a car, we hear it in the way in which it breaks in onto our world. To hear "bare" or pure sounds we would have to listen "away from things" in other words, "listen abstractly" (p. 26). Maurice MerleauPonty makes a similar point in the Phenomenology of Perception. Pure impressions are not only imperceptible but undiscoverable (1962, p. 4). We don't hear a pure sound sensation or "sense impression" but the barking of the dog or the ringing of the phone, or as Alphonso Lingis says, "The sounds we hear are chords, melodies, calls, cries, rattlings. We hear them in the midst of hum, rustling, rumble, static, clatter, or racket” (1996, p. 54).

Even if we hear a sound that we do not recognize we nevertheless recognize it as nonrecognizable and we may orient to its origin or nature. The point is that we are already engaged in a world where this sound acquires a particular meaning and significance. For example, I am driving my car and a familiar song comes on the radio; then suddenly I hear a strange rattling that makes me wonder if it originates in the engine or the tires on the road. Or I am having lunch in a coffee shop and the cell phone rings; I reach for the phone and then realize that it is not mine that rings. In such examples it is the meaningful context or the sense of our world in terms of which things come to our attention. For Heidegger, the source of intelligibility is more mundanely the context of meaning in which our practices are embedded.

Still, one could ask: how does the context gets its meaning? From Heidegger's perspective one cannot really account for the context since we already live it, before we make sense of it in an interpretive manner. We live out that context by constantly actualizing and realizing our understandings that already inhere in our practices and that cannot necessarily be explicated. In his reading of Heidegger's Being and Time, Dreyfus repeatedly uses the term "practice" to interpret the interpretive structure of Heidegger's notion of being. He discusses Heidegger's notion of meaning or "sense" in terms of "the background practices on the basis of which all activities and objects are intelligible or make sense" (Dreyfus, 1990, p. 223). We first of all understand the world through the equipment and practices within which we dwell. This understanding is preontological. We understand our world without noticing the background practices in terms of which our understandings are experienced as being in the world in a certain way.

If we now ask how the pragmatic notion of practice can be brought into the discussion of how our everyday life experiences can be understood then it appears that a phenomenological descriptive (rather than a deterministic cultural structuralist) view of practice can actually 
mediate the epistemology of Husserl and the ontology of Heidegger. At a primal level of originary existence, our practices too are tacit, prereflective, preconscious, and thus inaccessible or elusive to objectivistic observation.

Practice theorists have invested founding significations in the concept of practice. But in their theoretical explications practice ultimately remains an elusive notion. For example, the French anthropologist Pierre Bourdieu gives a Heideggerian account of the noncognitive and corporeal nature of everyday practices:

Principles embodied ... are placed beyond the grasp of consciousness, and hence cannot be touched by voluntary, deliberate transformation, cannot even be made explicit; nothing seems more ineffable, more incommunicable, more inimitable, and, therefore, more precious, than the values given body, made body by the transubstantiation achieved by the hidden persuasion of an implicit pedagogy, capable of instilling a whole cosmology, an ethic, a metaphysic, a political philosophy, through injunctions as insignificant as "stand up straight" or "don't hold your knife in your left hand". (Bourdieu 1977, p. 94)

From a phenomenological perspective these supposed imitated or learned practices are not "rules" in an ethnomethodological sense, but rather a kind of corporeal in-being: a preontological understanding of being. Whereas ontology concerns itself with the being (intelligibility) of beings, preontology is concerned with the modes of being of Dasein. But this corporeal knowing that inheres in our everyday practices is not something that can be easily made explicit by phenomenology either. And yet, we can see how human beings live through the practices in a mimetic and formative relation to their others. Bourdieu says,

The child imitates not "models" but other people's actions. Body hexis speaks directly to the motor function, in the form of a pattern of postures that is both individual and systematic, because linked to a whole system of techniques involving then body and tools, and charged with a host of social meanings and values: in all societies, children are particularly attentive to the gestures and postures which in their eyes, express everything that goes to make an accomplished adult - a way of walking, a tilt of the head, facial expressions, ways of sitting and of using implements, always associated with a tone of voice, a style of speech, and (how could it be otherwise?) a certain subjective experience (Bourdieu 1977, p. 87).

The question of the meaning of practice raises primarily an issue of intelligibility. Practice, in its social constructionist version, is not only meant to mean something, practice is supposed to make it possible to explain, interpret or understand the nature of the phenomena within its scope. But from a phenomenological perspective, constructionist approaches to practice too easily involve reifying what escapes reification, thematizing what cannot be thematized, and bringing practice within the reach of objectivistic technological thought. 


\section{The pervasiveness of technological and calculative practice}

In professional fields such as pedagogy, psychology and nursing, the dominance of technological and calculative thought is so strong that it seems well-nigh impossible to offer acceptable alternatives to the technocratic ideologies and the inherently instrumental presuppositional structures of professional practice. The roots of this technologizing of professional knowledge have grown deeply into the metaphysical sensibilities of western cultures. There is a certain irony in the fact that even the increasing popularity of qualitative inquiry has actually resulted in professional practice becoming cemented ever more firmly into preoccupations with calculative policies and technological solutions to standards of practice, codes of ethics, and perceived problems.

On the basis of an onto-theological reading of Heidegger's writings on technology and metaphysics, Iain Thomson (2005) traces the historical Heideggerian account of the present hegemony of technological and calculative thought. Since the early days of Western thought, being (the being of entities) has been interpreted as the metaphysical foundation in which the reality and meaning of every entity is grounded. The Real has been understood in terms of the existence of the world and the things (existents) that make up the real. Ontology establishes and shapes our understanding of being or what "is" — ti estin and hoti estin. Ti estin is the question of whatness: what something is. And hoti estin is the concern with thatness: that something is. Since Plato and Aristotle, Western metaphysics has been understood in terms of this distinction between whatness and thatness, essence and existence. It is strange, perhaps, that the enigma of existence tends to be past over in our quest to understand the whatness of things. But even more puzzling is the question wherein the difference of the distinction between whatness and thatness resides.

Heidegger shows how with Friedrich Nietzsche's notion of the "eternally recurring willto-power," our (post)modern sensibility of reality has become a metaphysics of nihilistic enframing that treats all entities (including human beings) instrumentally, available for our use. This last historical Western epoch of being is the declared end of metaphysics, and, according to Heidegger, it has led to a thoughtless nihilism that reduces all intelligibility to technological sensibility: viewing anything that exists as infinite, and thus without end, meaning, or purpose. However, in Heidegger's view, Nietzsche's philosophy of will-to-power is still based on a metaphysics - a metaphysics that has forgotten its own forgetfulness of being. Instead, the being of entities is pervasively viewed within a calculative rationality. Even our interest in quality and qualitative concerns tends to become reduced to and absorbed by the instrumental and quantitative preoccupations. In Thomson's words, "our technological understanding of being produces a calculative thinking that quantifies all qualitative relations, reducing entities to bivalent, programmable 'information'" (Thomson, 2005, p. 56).

The consequences of the present onto-theology have led to a practice of living that is profoundly affected by technological sensibilities. Thus, Thomson observes how in educational contexts, terms such as "excellence," "potential," and "quality" have lost their substantive and normative content. Striving for a higher pedagogical quality of education becomes a quantitative concern with what can be measured in terms of outcomes, observables, and standards. Presently, the meaning of purpose and human potential is merely seen in terms of "empty imperatives" such 
as: "Get the most out of your potential!" (Thomson, 2005, p. 22). Our Nietzschean rejection of reflection on being and ground lets us forget our forgetfulness. At present it is fashionable to level the charge of "foundationalism," the supposition that we can ground our practices in something certain, unchanging or absolute. But the real danger, says Thomson, is not the search for a sense of foundation or ground, but the predicament that we forget that something has been forgotten. According to Thomson shallow antifoundationalism merely surrenders us to a thoughtless and inattentive onto-theology "that preconceives all entities as intrinsically meaningless resources merely awaiting optimization" (Thomson, 2005, p. 41).

\section{A phenomenology of practice grasps the world pathically}

A phenomenology of practice is challenged to free itself of calculative rationality. In fact, the primal or pre-theoretical dimensions of practice are tied into the ontology of being and knowing. What distinguishes practice from theory is not that practice applies thought or concepts technically to some real thing in the world upon which it acts. Rather, the phenomenology of practice involves a different way of knowing the world. Whereas theory "thinks" the world, practice "grasps" the world — it grasps the world pathically (van Manen, 1997; 1999).

The competence of professional practitioners is itself largely tied into pathic knowledge. Professional knowledge is pathic to the extent that the act of practice depends on the sense and sensuality of the body, personal presence, relational perceptiveness, tact for knowing what to say and do in contingent situations, thoughtful routines and practices, and other aspects of knowledge that are in part prereflective, pre-theoretic, pre-linguistic. If we wish to further study and enhance such pathic dimensions of professional practice we need a language that can express and communicate these understandings. This language needs to remain oriented to the experiential or lived sensibility of the lifeworld. For example, experiential stories provide opportunities for evoking and reflecting on practice. Eugine Gendlin suggests that this kind of understanding is not cognitive in the usual sense. He says: "It is sensed or felt, rather than thought—and it may not even be sensed or felt directly with attention" (Gendlin, 1979, p. 45). Nevertheless, our sense of the pathic in our own or in other people's existence can become a topic for our reflection.

On first glance the term pathic relates to the terms of a discourse, as in, em-pathic and sym-pathic. Empathy and sympathy are usually discussed as certain types of relational understandings that involve imaginatively placing oneself in someone else's shoes, feeling what the other person feels, understanding the other from a distance (telepathy), or more generally, to be understandingly engaged in other people's lives. We acknowledge that there are other modalities of pathic understanding. But the first important point is that the terms empathy and sympathy suggest that this understanding is not primarily gnostic, cognitive, intellectual, technical - but rather that it is, indeed, pathic: relational, situational, corporeal, temporal, actional.

The term pathic derives from pathos, meaning "suffering and also passion." In a larger life context, the pathic refers to the general mood, sensibility, sensuality, and felt sense of being in the world. Lingis would say that there is pathic intelligibility in sensual sensibility (Lingis, 
1996). The pathically tuned body recognizes itself in its responsiveness to the things of its world and to the others who share our world or break into our world. The pathic sense perceives the world in a feeling or emotive modality of knowing and being. Buytendijk (1970) draws a close relation between the pathic experience and the mood of the lived body. Similarly, Heidegger uses the notion of Befindlichkeit to refer to this sense that we have of ourselves in situations. Literally Befindlichkeit means, "the way one finds oneself" in the world (Heidegger, 1962, pp. 172-188). We have an implicit, felt understanding of ourselves in situations even though it is difficult sometimes to put that understanding into words.

Now, it is much easier for us to teach concepts and informational knowledge than it is to bring about pathic understandings. But herein lies the strength of a phenomenology of practice. It is through pathic significations and images, accessible through phenomenological texts that speak to us and make a demand on us, that the more noncognitive dimensions of our professional practice may be communicated, internalized and reflected on. For this we need to develop a phenomenology that is sensitive to the thoughtfulness required in contingent, moral, and relational situations.

Second, it is much easier to describe the cognitive than the pathic aspects of our world. For the sake of making a somewhat oversimplified distinction, the cognitive aspects are the conceptual, objective, measurable features of something. For example, we may describe an architectural or physical space, such as a school or church, in terms of its dimensional properties and measures. But such spaces also have their atmospheric, sensual, and felt aspects. Moreover, these pathic qualities are not fixed but subject to change like moods of a landscape. In this sense we can speak of the pathic sensibility of a school, a classroom, an office, a hospital or any environment where professional practitioners work agogically (in service, teaching, healing, helping, counseling, or ministering relations) with others.

Much research starts from the assumption that knowledge is cognitive and reflective and thus it already passes over other, more pathic forms of knowing that may actually constitute a major dimension of our experience and practice. In the early sixties the psychologist Erwin Strauss (Strauss, 1966) wrote that in the human and social sciences it has always been the intellectual or cognitive factors and never the pathic facets that have been studied and researched. By pathic he meant the immediate or unmediated and preconceptual relation we have with the things of our world.

While the word "pathic" has rarely, if ever, been systematically employed, certain aspects of meaning underlying pathic knowledge are not new. There has been increased attention given to the phenomenon of embodiment in human action. From a phenomenological point of view it can even be argued that the whole body itself is pathic. Thus "the body knows" how to do things, such that, if we wanted to gain intellectual control of this "knowledge" we might in fact hamper our ability to do the things we are doing - of course, these include routines, habits, motoric skills and memories, conventions, rules, etcetera. Merleau-Ponty (1962) described the body subject (corps sujet) in terms of the access it provides to our world. But it could also be argued that such pathic knowledge does not only inhere in the body but also in the things of our world, in the situation(s) in which we find ourselves, and in the very relations that we maintain with others and the things around us. For example, pathic "knowledge" also expresses itself in the confidence with which we do things, the way that we "feel" the atmosphere of a place, the 
manner in which we can "read" someone's face, and so forth. Knowledge inheres in the world already, in such a way, that it enables our embodied practices.

The pathic dimensions of practice are pathic precisely because they reside or resonate in the body, in our relations with others, in the things of our world, and in our very actions. These are the corporeal, relational, temporal, situational, and actional kinds of knowledge that cannot necessarily be translated back or captured in conceptualizations and theoretical representations. In other words, there are modes of knowing that inhere so immediately in our lived practices-in our body, in our relations, and in the things around us - that they seem invisible (see van Manen, 1997).

However, knowledge does manifest itself in practical actions. And we may "discover" what we know in how we act and in what we can do, in the things of our world, in our relations with others, in our embodied being, and in the temporal dimensions of our involvements. Even our gestures, the way we smile, the tone of our voice, the tilt of our head, and the way we look the other in the eye are expressive of the way we know our world and comport ourselves in this world.

On the one hand, our actions are sedimented into habituations, routines, kinesthetic memories. We do things in response to the rituals of the situation in which we find ourselves. On the other hand, our actions are sensitive to the contingencies, novelties, and expectancies of our world.

Ordinary cognitive discourses are not well suited to address noncognitive dimensions of professional experience. A pathic language is needed in order to evoke and reflect on pathic meanings. Pathic understanding requires a language that is sensitive to the experiential, moral, emotional and personal dimensions of professional life. For example, we need to employ certain writing methods in order to orient to the pedagogical dimensions of teaching, the healing dimensions of medicine, the therapeutic dimensions of psychology. This is where human science inquiry and especially the process of phenomenological writing may play a helpful role (see van Manen, 1997; 2002). Through a certain kind of phenomenological writing (described below) these pathic forms of knowing may find expression in texts, which make demands on us that find expression in our practices. This phenomenological writing constitutes a phenomenology in practice and promotes a phenomenology of and for practice.

\section{Phenomenology of sensitive practice}

An early form of this kind of phenomenological writing was exercised in the phenomenological texts by proponents of the so-called Dutch or University of Utrecht tradition (see Levering and Van Manen, 2002). The Utrecht School consisted of an assortment of phenomenologically oriented psychologists, educators, pedagogues, pediatricians, sociologists, criminologists, jurists, psychiatrists, and other medical doctors. Scholars such as Van den Berg (1966, 1972), Beets (1952/75), Langeveld (1983), Linschoten (1987) and Buytendijk (1943) integrated phenomenological method into the very languages and structures of their disciplines. They shied away from technical philosophical issues and they openly admitted that they were primarily 
interested in phenomenology as a practical and reflective method, not in phenomenology as professional philosophy.

On the whole the various scholars of the Utrecht School seemed more than interested in doing phenomenology in service of their professional disciplines or more generally for the purpose of understanding the practices of everyday life. And so, what they did do - each in their unique way - was produce what were often compellingly insightful, textual portrayals of concrete human phenomena. This interest in mundane everyday concerns is evident in writings on topics such as "Having a Conversation" (van den Berg), "The Hotel Room" (van Lennep), "The Secret Place in the Life of the Child" (Langeveld), "Experiencing Obsessive Compulsions" (Buytendijk), and "Insomnia and Falling Asleep" (Linschoten).

Langeveld termed the work of the Utrecht School a "home, kitchen, street" approach to phenomenological inquiry. He was interested in doing practical phenomenology and he proclaimed that he was not interested in philosophical questions about indubitable knowledge or the conditions of phenomenological understanding. For example, in his text "The Secret Place in the Life of the Child," Langeveld gives the reader a resonating understanding of the "felt meaning" of that special place that young children at times seem to seek out. The "secret place" is the place where the child withdraws from the presence of others.

Langeveld sensitively describes what it is like for a child to quietly sit in this place where the adult does not pay attention. This special space experience does not involve the child in activities such as hide and seek, spying on others, doing mischief, or playing with toys. Rather, what we see is that the child just sits there, while perhaps gazing dreamingly into the distance. What is going on here? Langeveld describes this space experience as a place of growth.

The child may find such space experience perhaps under a table, behind a heavy curtain, inside a discarded box, or wherever there is a corner where he or she can hide or withdraw. This is where the child may come to "self-understanding," as it were. Langeveld's intention is to show the formative pedagogical value of the experience of the secret place for the growing child. He describes it as "normally an unthreatening place for the young child to withdraw" (1983a, p. 13). Langeveld says things like: "the actual experience of the secret place is always grounded in a mood of tranquility, peacefulness: It is a place where we can feel sheltered, safe, and close to that with which we are intimate and deeply familiar" (1983a, p. 13). He portrays the various modalities in terms of which the secret place may be experienced. Sometimes the child experiences space as something uncomfortable, as looming danger:

The phenomenological analysis of the secret place of the child shows us that the distinctions between the outer and inner world melt into a single, unique, personal world. Space, emptiness, and also darkness reside in the same realm where the soul dwells. They unfold in this realm and give form and sense to it by bringing this domain to life. But sometimes this space around us looks at us with hollow eyes of disappointment; here we experience the dialogue with nothingness; we are sucked into the spell of emptiness, and we experience the loss of a sense of self. This is also where we experience fear and anxiety. The mysterious stillness of the curtain, the enigmatic body of the closed door, the deep blackness of the grotto, the stairway, and the spying window which is placed too high to look through, all 
these lead to the experience of anxiety. They may seem to guard or cover an entry-way or passage. The endless stairway, the curtains which move by themselves, the door which is suspiciously ajar, or the door which slowly opens, the strange silhouette at the windows are all symbols of fear. In them we discover the humanness of our fears. (1983a, p. 16)

But during the fourth and fifth year of life the "I" gradually begins to assert itself against the world, the anxieties disappear in degrees. These are the beginnings of the initial developments of a unique human personality in which the first opposition between world and "I" becomes conscious and in which the world is experienced as "other," says Langeveld. Now the secret space becomes invitational:

The indeterminate place speaks to us, as it were. In a sense, it makes itself available to us. It offers itself, in that it opens itself. It looks at us in spite of the fact and because of the fact that it is empty. This call and this offering of availability are an appeal to the abilities of the child to make the impersonal space into his very own, very special place. And the secrecy of this place is first of all experienced as the secrecy of "my-own-ness." Thus in this void, in this availability, the child encounters the "world." Such an encounter the child may have experienced before in different situations. But this time it encounters the world in a more addressable form -- everything which can occur in this openness and in this availability, the child must actively fashion or at least actively allow as a possibility. (1983a, p. 17)

In spite of quoting these sentences from Langeveld, it is quite impossible to summarize or paraphrase Langeveld's text since it is precisely the quality of the entire text that leads one to recognize reflectively what the experience may be like for a child. In "The Secret Place in the Life of the Child" we can also observe how Langeveld locates the normative in the phenomenological account of the experience of the secret place. He shows not only what the experience is like he also shows how it is a pedagogically appropriate experience for the child:

In the secret place the child can find solitude. This is also a good pedagogical reason to permit the child his secret place ... something positive grows out of the secret place as well, something which springs from the inner spiritual life of the child. That is why the child may actively long for the secret place.

During all the stages leading to adulthood, the secret place remains an asylum in which the personality can mature; this self-creating process of this standing apart from others, this experiment, this growing self-awareness, this creative peace and absolute intimacy demand it -- for they are only possible in alone-ness. (1983a, p. 17) 
Langeveld argues that it is inevitable to see how the normative is intimately linked to our understanding of children's experiences since we are always confronted with real life situations wherein we must act: we must always do what is appropriate in our interactions with children. From the perspective of Langeveld's pedagogical interest in children, a phenomenology of practice sponsors a pedagogical sensitivity that expresses itself in tactfulness on the part of the adult.

Some may feel uncomfortable with the way in which phenomenologists like Langeveld seem to reach deeply into the stylistic realms of the humanities. Often the texts by proponents of the Utrecht School are not only insightful but also evocative. They speak to us and they may stir our pedagogical, psychological or professional sensibilities. In accounting for this poetic feature of these phenomenological texts Joseph Kockelmans says:

Often an appeal to poetry and literature is almost unavoidable in that poetic language with its use of symbolism is able to refer beyond the realm of what can be said "clearly and distinctly." In other words ... in human reality there are certain phenomena which reach so deeply into a man's life and the world in which he lives that poetic language is the only adequate way through which to point to and to make present a meaning which we are unable to express clearly in any other way. (1987, p. ix)

Now we may wonder, in what sense does the inclusion of pieces of literature, poetry, anecdotal portrayals, and images play a part in the pathic power of the text?

In his wonderfully subtle The Poetics of Space, Gaston Bachelard makes a distinction that is evocative as well as transformative. He employs the notion of the "poetic image" to refer to that special epiphanic quality of language that brings about, in the reader, what he calls a phenomenological reverberation (1964, p. xxiii). The power of phenomenological texts lies precisely in this resonance that the word can effect in our understanding, including those reaches of understanding that are somehow pre-discursive and pre-cognitive and thus less accessible to conceptual and intellectual thought. The creative contingent positioning of words may give rise to evoked images that can move us: inform us by forming us and thus leave an effect on us. When this happens, says Gadamer (1996), then language touches us in the soul. Or as Bachelard puts it, the reverberations bring about a change of being, of our personhood (1964, p. xviii). He says,

The image has touched the depths before it stirs the surface [of our being or self]. And this is also true of a simple experience of reading. The image offered us by reading the poem now becomes really our own. It takes roots in us. It has been given us by another, but we begin to have the impression that we could have created it, that we should have created it. It becomes a new being in our language, expressing us by making us what it expresses; in other words, it is at once a becoming of expression, and a becoming of our being. Here expression creates being. (1964, p. xix) 
Perhaps a phenomenological text is ultimately successful only to the extent that we, its readers, feel addressed by it - in the totality or unity of our being. The text must reverberate with our ordinary experience of life as well as with our sense of life's meaning. This does not necessarily mean that one must feel entertained by phenomenological text or that it has to be an "easy read." Sometimes reading a phenomenological study is a truly laborious effort. And yet, if we are willing to make the effort then we may be able to say that the text speaks to us not unlike the way in which a work of art may speak to us even when it requires attentive interpretive effort.

To reiterate, we may say that a phenomenology of practice operates in the space of the formative relations between who we are and who we may become, between how we think or feel and how we act. And these formative relations have pedagogical consequence for professional and everyday practical life. Phenomenological reflection — reading and writing of phenomenological texts - can contribute to the formative dimensions of a phenomenology of practice. By varying the prefixes of the derivatives of "the formative," the various formative relations may become manifest. Phenomenology formatively informs, reforms, transforms, performs, and performs the relation between being and practice. In-formatively, phenomenological studies make possible thoughtful advice and consultation. Re-formatively, phenomenological texts make a demand on us, changing us in what we may become. Transformatively, phenomenology has practical value in that it reaches into the depth of our being, prompting a new becoming. Per-formatively, phenomenological reflection contributes to the practice of tact. And pre-formatively, phenomenological experience gives significance to the meanings that influence us before we are even aware of their formative value.

\section{References}

Bachelard G. (1964). The poetics of space. Boston: Beacon Press.

Beets, N. (1952/75). Verstandhouding en Onderscheid: Een Onderzoek naar de Verhouding van Medisch en Pedagogisch Denken. Amsterdam: Boom Meppel.

Bourdieu, P. (1977). Outline of a theory of practice. Cambridge: Cambridge University Press.

Buytendijk, F.J.J. (1943). Over de pijn. Utrecht: Het Spectrum.

Buytendijk, F.J.J. (1970). Some aspects of touch. Journal of Phenomenological Psychology 1(1) 99-124.

Dreyfus, H. (1990). Being-in-the-world: A commentary on Heidegger's Being and Time, Division I. Cambridge, Mass: MIT Press.

Gadamer, H-G. (1998). Praise of theory. New Haven: Yale University Press. 
Gendlin, E.T. (1979). Befindlichkeit: Heidegger and the philosophy of psychology. Review of Existential Psychology and Psychiatry 16(1-3) 48-60.

Heidegger, M. (1962). Being and time. New York: Harper \& Row.

Heidegger, M. (1975). Poetry, language, and thought. New York: Harper \& Row.

Heidegger, M. (1985). History of the concept of time. Bloomington: Indiana University Press.

Heidegger, M. (2000). Introduction to metaphysics. New Haven \& London: Yale University Press.

Husserl, E. (1970). The crisis of the European sciences and transcendental phenomenology. Evanston: Northwestern University Press.

Husserl, E. (1964). The phenomenology of internal time-consciousness. Bloomington: Indiana University Press.

Kockelmans, J.J. (Ed.). (1987). Phenomenological psychology: The Dutch School. Dordrecht: Kluwer.

Langeveld, M.J. (1983a). The stillness of the secret place. Phenomenology and pedagogy 1(1) 11-17.

Langeveld, M.J. (1983b). The secret place in the life of the child. Phenomenology and pedagogy 1(2) 181-194.

Levering, B. \& van Manen, M. (2002). Phenomenological anthropology in the Netherlands and Flanders. In T. Tymieniecka (Ed.), Phenomenology world-wide (pp. 274-286). Dordrecht: Kluwer.

Lingis, A. (1996). Sensation: Intelligibility in sensibility. Amherst, NY: Humanity Books.

Linschoten, J. (1987). On falling asleep. In: J.J. Kockelmans (Ed.), Phenomenological psychology: The Dutch school. (pp. 79-118). Dordrecht/Boston: Martinus Nijhoff Publishers.

Merleau-Ponty, M. (1962). Phenomenology of perception. London: Routledge \& Kegan Paul.

Payne, M. and Schad, J. (Eds.) (2003). life.after.theory. London: Continuum.

Rilke, R.M. (1987). The notebooks of Malte Laurids Brigge. Oxford: Oxford University Press. 
Rilke, R.M. (1987). Rilke and Benvenuta: An intimate correspondence. New York: Fromm International.

Straus, E.W. (1966). Phenomenological psychology. New York: Basic Books. Thomson, I. D. (2005). Heidegger on ontotheology: Technology and the politics of education. Cambridge: Cambridge University Press.

Van den Berg, J.H. (1966). The Psychology of the sickbed. Pittsburgh.: Duquesne University Press.

Van den Berg, J.H. (1972). A different existence: Principles of phenomenological psychopathology. Pittsburgh: Duquesne University Press.

van Manen, M. (1991). The tact of teaching: The meaning of pedagogical thoughtfulness. London, ON.: Althouse Press.

van Manen, M. (1997). Researching lived experience: human science for an action sensitive pedagogy. London, ON.: The Althouse Press.

van Manen, M. (1999). The pathic nature of inquiry and nursing. In: Madjar, Irena and Walton, Jo (eds.), Nursing and the experience of illness: phenomenology in practice (pp. 17-35.) London: Routledge.

van Manen, M. (Ed.). (2002). Writing in the dark: Phenomenological studies in interpretive inquiry. London, ON.: Althouse Press. 